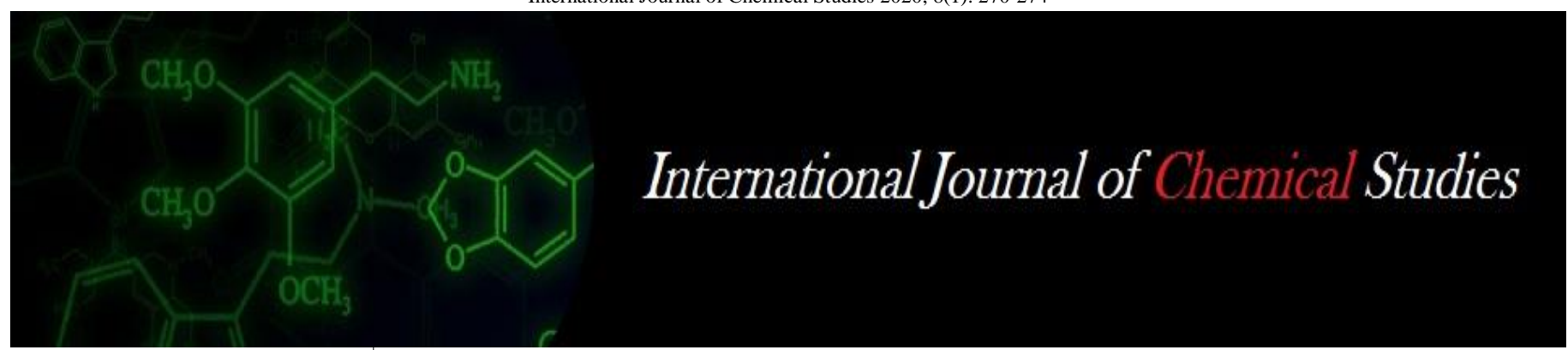

P-ISSN: 2349-8528

E-ISSN: 2321-4902

IJCS 2020; 8(1): 270-274

(C) 2020 IJCS

Received: 04-11-2019

Accepted: 06-12-2019

Pravesh Kumar

Department of Soil Science and Agricultural Chemistry, College of Agriculture, Narendra Deva University of Agriculture and Technology, Kumarganj, Ayodhya, Uttar Pradesh, India

Raj Kumar Pathak

Department of Soil Science and Agricultural Chemistry, College of Agriculture, Narendra Deva University of Agriculture and Technology, Kumarganj,

Ayodhya, Uttar Pradesh, India

Amar Singh Gaur

Department of Soil Science and Agricultural Chemistry, College of Agriculture, Narendra Deva University of Agriculture and Technology, Kumarganj, Ayodhya, Uttar Pradesh, India

Devi Prasad Shukla

Sheila Dhar Institute of Soil

Science, Department of

Chemistry, University of Allahabad, Allahabad, Uttar

Pradesh, India.

\section{Gajraj Yadav}

Department of Soil Science and Agricultural Chemistry, College of Agriculture, Narendra Deva University of Agriculture and Technology, Kumarganj, Ayodhya, Uttar Pradesh, India

Corresponding Author:

Pravesh Kumar

Department of Soil Science and Agricultural Chemistry, College of Agriculture, Narendra Deva University of Agriculture and Technology, Kumarganj, Ayodhya, Uttar Pradesh, India

\section{Effect of weed management practices on physico- chemical and biological properties of soils in wheat crop}

\author{
Pravesh Kumar, Raj Kumar Pathak, Amar Singh Gaur, Devi Prasad \\ Shukla and Gajraj Yadav
}

Abstract

The present investigation entitled "Effect of weed management practices on Physico-chemical and biological properties of soils in wheat crop" was conducted at Agronomy Research Farm of N.D. University of Agriculture \& Technology, Kumarganj, Ayodhya during Rabi season 2016-2017. The experiment was laid out in randomized block design with three replications. There were ten treatments viz: $\mathrm{T}_{1}$-Sulfosulfuran (POE) @ $0.03 \mathrm{~kg} / \mathrm{ha}, \mathrm{T}_{2}$-Clodinafop + Metsulfuran (RM) (POE) @ $0.06+0.004$ $\mathrm{kg} / \mathrm{ha}, \mathrm{T}_{3}$-Fenoxaprop p-ethyl + Metribuzin (RM) (POE) @ $0.1+0.075 \mathrm{~kg} / \mathrm{ha}, \mathrm{T}_{4}$-Metsulfuran methyl + Iodosulfuran methyl (RM) (POE) @ $0.012+0.0024 \mathrm{~kg} / \mathrm{ha}, \mathrm{T}_{5}$-Sulfosulfuran + metsulfuran (RM) (POE) @ $0.03+0.002 \mathrm{~kg} / \mathrm{ha}, \mathrm{T}_{6}-\mathrm{Pendimethalin}+2,4-\mathrm{D} \mathrm{Na}(\mathrm{PE}) @ 1+0.5 \mathrm{~kg} / \mathrm{ha}, \mathrm{T}_{7}$ - Metribuzin (POE) @ $0.175 \mathrm{~kg} / \mathrm{ha}, \mathrm{T}_{8}-2,4-\mathrm{D} \mathrm{Na}$ ) (POE) @ $0.5 \mathrm{~kg} / \mathrm{ha}, \mathrm{T}_{9}$-weed free up to $60 \mathrm{DAS}$ (3 HW), T10-weedy check. The soil of experimental field was silt loam in texture having low organic carbon, nitrogen and phosphorus and medium in potash. The wheat variety HUW-234 was sown on 04th Dec, 2016 in rows 20 cm apart using seed @ 125 kg ha-1. Recommended dose of fertilizers were applied @ 120:60:40 kg ha-1 $\mathrm{N}$ : P: K. Among the different weed management practices weed free up to 60 DAS $(3 \mathrm{HW})$ were found better on the Physico-chemical properties likes, Bulk density $1.27(\mathrm{Mg} / \mathrm{m} 3), \mathrm{pH} 8.0, \mathrm{EC} 0.22\left(\mathrm{dSm}^{-1}\right)$, OC $3.35(\%)$ but biological properties was found better result in $\mathrm{T}_{10^{-}}$weedy check (control plot) likes Bacteria 34.0 (cfu $\times 10^{6}$ ), Fungi 18.0 (cfu x $10^{6}$ ) population. Thus it may be concluded that weed free up to 60 DAS $(3 \mathrm{HW})$ was found suitable physical, chemical properties and weedy check (control plot) biological properties of soils than the rest of chemical treatments.

Keywords: Wheat, physico-chemical, biological, herbicide

\section{Introduction}

Wheat (Triticum aestivum L.) is staple food of the world and falls under poaceae family. It is primarily grown in temperate regions and also at higher altitude under tropical climatic areas in winter season. It is the single most important cereal crop that has been considered as integral component of the food security system of the several nations. It is eaten in various forms more than one thousand million human being in the World. In the terms of production wheat occupies the prime position among the food crop in the world. It ranks first in the world among the cereals both in respect of acreage (219 $\mathrm{m} \mathrm{ha}$.) and production $(758.38 \mathrm{Mt}$.). In India, it is cultivated on an area of $30.79 \mathrm{~m}$ ha. Having productions of 98.51 million tonnes with a productivity of $3.20 \mathrm{t}$ ha-1. It contributes about 34 percent of total food grain production of the country (USDA 2017-18). About 91 percent of the total wheat production is contributed by Northern states. Among them Uttar Pradesh rank first with respect to area $9.65 \mathrm{~m}$ ha and production $26.87 \mathrm{Mt}$, but the productivity is much lower $3.48 \mathrm{t}$ ha-1 as compared to Punjab and Haryana $4.50 \mathrm{t} \mathrm{h}-1$ (Agricultural Statistics at a glance 2015-16).

The productivity of wheat in eastern Uttar Pradesh is very low which might be due to the adoption of cereal- cereal (Rice-Wheat) cropping system, irrigation, poor weed management, poor soil health and imbalance fertilizer used weed reduces wheat yield if not controlled in the critical stages of crop and may cause yield reduction up to 60\% (Angiras et al., 2008) ${ }^{[1]}$. Chemical weed control is a preferred practice due to scarce and costly labour as well as lesser feasibility of mechanical or manual weeding. There is a need to applied new molecules of herbicides, without so, harming the soil health. Soil being the store house of multitude of microbes, in quantity and quality, receives the chemicals in various forms and acts as a scavenger of the harmful substances. 
This may affect the overall microbial population of the soil, of which some of them may be selectively inhibited or killed. However, soil micro-organisms, being in returns to its original form after few month. Continued application of large quantities of herbicides may bring about lasting changes in the soil micro flora, ultimately affecting its fertility level (Rangaswami and Bagyaraj, 2004) ${ }^{[21]}$. The effect of herbicides application on soil health (microbial environment) is always in direct concern distortion microbial growth Kumar et al. (2014) ${ }^{[12]}$. The growths of different microbial activity have been reduced due to application of different herbicide (Shukla and Mishra, 1997).

\section{Materials and Methods}

\subsection{Experimental site}

The geographical location of Ayodhya district lies between latitude 42.470 and 25.560 North and longitudes 18.120 and 83.980 east and at an altitude of 113 meters in the Gang tic alluvium of eastern Uttar Pradesh. The experiment was conducted at the Agronomy Research Farm of Narendra Deva University of Agriculture and Technology, Narendra Nagar (Kumarganj), Ayodhya (U.P.). The experimental site is situated about $42 \mathrm{~km}$, away from Ayodhya city, on Ayodhya, Raibareilly road.

\subsection{Soil properties of initial soils}

The soil of the experimental farm was silt loam in texture. The samples from $(0-15 \mathrm{~cm})$ depth were collected for Physico-chemical and biological analysis before execution of the experimental treatments. The details of the Physicochemical and biological properties of the experimental soil have been given in table 01 .

Table 1: Physico-chemical and biological properties of initial soil

\begin{tabular}{|c|c|c|}
\hline S. No. & Characteristics & (2016-17) value \\
\hline A. & Physical properties \\
\hline 1. & Bulk density $\left(\mathrm{Mg} / \mathrm{m}^{3}\right)$ & 1.35 \\
\hline 5. & Soil texture & Silt loam \\
\hline B. & Chemical Properties & \\
\hline 1. & pH (1:2.5) & 8.20 \\
\hline 2. & E.C. (dSm-1) & 0.24 \\
\hline 3. & Organic Carbon (g kg-1,) & 3.10 \\
\hline C. & Biological Properties & \\
\hline 1. & Bacterial population (cfu g-1 x 106) & 15.00 \\
\hline 2. & Fungal population (cfu g-1 x 104) & 11.48 \\
\hline
\end{tabular}

\# Cfu mean Colony forming unit

\subsection{Treatments details}

Table 2: Details of treatments with their symbols

\begin{tabular}{|c|c|c|c|}
\hline S. No. & Details of treatments & Time (DAS) & Symbols \\
\hline 1 & Sulfosulfuran @0.03 kg/ha (POE) & $25-30$ & $\mathrm{~T}_{1}$ \\
\hline 2 & Clodinafop +Metsulfuran @ $0.06+0.004$ kg/ha (POE) (Vesta) & 30 & $\mathrm{~T}_{2}$ \\
\hline 3 & Fenoxaprop P-ethyl + Metribuzine @ 0.100+ 0.075 kg/ha (RM) (POE) & $25-30$ & $\mathrm{~T}_{3}$ \\
\hline 4 & Mesosulfuran Methyl + Idosulfuran Methyl @ 0.012+0.0024 kg/ha (RM) (POE) (Atlantis) & $25-30$ & $\mathrm{~T}_{4}$ \\
\hline 5 & Sulfosulfuran +Metsulfuran @ $0.030+0.002 \mathrm{~kg} / \mathrm{ha}(\mathrm{RM})(\mathrm{POE})$ (Total) & $25-30$ & $\mathrm{~T}_{5}$ \\
\hline 6 & Pendimethaline + 2, 4-D Na @ 1+0.5 kg/ha (PE) & $0-3,30$ & $\mathrm{~T}_{6}$ \\
\hline 7 & Metribuzine @ 0.175 kg/ha (POE) & $25-30$ & $\mathrm{~T}_{7}$ \\
\hline 8 & 2, 4-D Na@0.5 kg/ha (POE) & 30 & $\mathrm{~T}_{8}$ \\
\hline 9 & Weed Free Up to 60 DAS (3 HW) & & $\mathrm{T}_{9}$ \\
\hline 10 & Weedy check & & $\mathrm{T}_{10}$ \\
\hline
\end{tabular}

\# POE mean post emergence, RM mean ready mix, PE mean pre emergence, DAS mean days after sowing, HW mean hand weeding

\subsection{Experimental details}

- Design adopted: Randomized Block Design

- Number of replication: Three (3)

- Total number of treatments: 10

- Total number of plot: 30

- Plot border: $0.5 \mathrm{~m}$

- Block border: $1.0 \mathrm{~m}$

- $\quad$ Field border: $1.0 \mathrm{~m}$

- Sub irrigation channel: $1.0 \mathrm{~m}$

- Row to Row spacing: $20 \mathrm{~cm}$

\subsection{Field Preparation and Fertilizer application}

With an object to obtain optimum moisture condition for proper germination of seed, a pre-sowing irrigation (Palewa) was applied in the experimental field. At proper tilth field was ploughed once with the tractor drawn soil turning plough followed by cross harrowing with the help of cultivator. Thereafter, planking was done to level the field and obtain fine tilth which is necessary for appropriate germination. As for possible the stubbles of previous rice crop and weeds were removed manually from the field. After land preparation, the layout of experiment was done on $4^{\text {th }}$ December, 2016. Urea, single super phosphate and muriate of potash were used to supply $120 \mathrm{~kg} \mathrm{~N}, 60 \mathrm{~kg} \mathrm{P}_{2} \mathrm{O}_{5}$ and $40 \mathrm{~kg} \quad \mathrm{~K}_{2} \mathrm{O} \quad \mathrm{ha}^{-1}$, respectively. Half dose of nitrogen and full doses of $\mathrm{P}_{2} \mathrm{O}_{5}$ and
$\mathrm{K}_{2} \mathrm{O}$ were applied as basal dressing. Remaining half dose of nitrogen through urea was top dressed in two equal doses.

\subsection{Seed and sowing}

Wheat cultivar HUW-234 was grown in the experimental field. The variety is double gene dwarf and matures in about 120 days. The sowing of crop was done manually by Kudali on $4^{\text {th }}$ December, 2016 in the rows at $20 \mathrm{~cm}$ apart and Seed rate was used as $125 \mathrm{~kg} \mathrm{ha}^{-1}$

\subsection{Irrigation and Plant protection measures}

Adequate soil moisture was maintained at all stages of crop growth. Four irrigations were given in the crop at crown root initiation, later tillering, flowering and dough stages of crop. There was no incidence of insect-pest and disease in the experimental field hence plant protection measures were not employed. Moreover, farmers of Eastern U.P. have never been seen practicing plant protection measures in wheat crop.

\subsection{Herbicides application}

Herbicides were applied according to treatments. Preemergence herbicides applied on $3^{\text {rd }}$ day of sowing and postemergence herbicides applied at 30 day after sowing of crop. Herbicides were sprayed with the help of manually operated knapsack sprayer fitted with flat fan nozzle using 600 litres water per hectare. 


\subsubsection{Harvesting and threshing}

Wheat should be harvested when the leaves and stems turn yellow and become finally dry. One row of border from both the side of the plot and $0.5 \mathrm{~m}$ from row length of both sides were harvested first and removed from the field to avoid error, often that net plot were harvested separately. Plot wise threshing was done very carefully by a power thresher. The grain yield of individual plot after winnowing was obtained and weighed. The quantity of straw per plot was calculated by subtracting the grain yield from the weight of the biological produce per plot. Later, the both grain and straw yield was computed in qha $^{-1}$ with the help of grain yield obtained out of net plot area.

\subsubsection{Collection of soil samples}

Soil samples (0-15 cm depth) were collected randomly from each experimental trail at initial and after harvest stage of the crop from each treatments. Soil samples were oven dried and processed for physic-chemical and biological analysis.

Table 3: Method employed and followed in soil analysis

\begin{tabular}{|c|c|c|}
\hline S. No. & Particulars & Extract used and method employed \\
\hline A. & & Physical properties \\
\hline 1. & Bulk density $\left(\mathrm{Mg} / \mathrm{m}^{3}\right)$ & Core sampler method (Richards, 1960) \\
\hline 2. & Soil texture & Triangular method (Lyon et al., 1933) \\
\hline B. & Chemical properties \\
\hline 1. & $\mathrm{pH}(1: 2 \cdot 5)$ & $(1: 2 \cdot 5)$ soil water suspension by Glass electrode pH meter (Jackson, 1973) \\
\hline 2. & E.C. $\left(\mathrm{dSm}^{-1}\right)$ & $(1: 2 \cdot 5)$ soil water suspension by Glass electrode EC meter (Jackson 1973) \\
\hline 3. & Organic Carbon $\left(\mathrm{g} \mathrm{kg}^{-1}\right)$ & Walkely and Blacks titration method (Walkely and Black, 1934) \\
\hline C. & \multicolumn{2}{|c|}{ Biological properties } \\
\hline 1. & Bacterial population $\left(\mathrm{cfu} \mathrm{g}^{-1}\right)$ & Serial Dilution Technique used Thornton's agar medium (Aneja K.R. 2003) \\
\hline 2. & Fungal population $\left(\mathrm{cfu} \mathrm{g}^{-1}\right)$ & Serial Dilution Technique used martin Rose Bengal agar medium (Aneja K.R. 2003) \\
\hline
\end{tabular}

\subsubsection{Statistical analysis}

The various data recorded in the experiment were analysed statistically with the help of electronic calculator following the procedure for randomized block design (RBD) given by Cochrane and Cox (1970) ${ }^{[6]}$. The standard errors of mean were calculated in each item of investigation and critical differences (CD) at 5\% level were worked out for comparing the treatment means wherever ' $F$ ' test was found significant. The analysis of the variance table has been given in the appendices. The data are illustrated with the help of diagrams wherever, felt necessary. The distribution of degree of freedom for various sources of variations is given as under in table.

SEm \pm : The standard error of mean for different main effects was calculated with the help of following Formula;

$\mathrm{SE} \pm$ : It was calculated with the help of following formula;

Critical difference (CD): It was calculated by the following formula

$\mathrm{CD}=\mathrm{SE} \pm \times{ }^{\prime} \mathrm{t}$ ' value at error degree freedom at $5 \%$

\section{Result and Discussion}

\subsection{Physical properties of soils}

Physical properties of soils are bulk density, soil texture, structure, particle density, water holding capacity etc. The Physical properties are important properties of soils for plant growth and development in soil. The physical properties provided the physical support to the plant. In this experiment studies about bulk density and soil texture affected by chemical weed management practices. The Data pertaining to bulk density and soil texture after harvest the crop have been presented in Table-4 clearly indicate that non-significant response were observed with respect to herbicides application on physical properties (BD and soil texture). Among all treatments the maximum bulk density $\left(1.33 \mathrm{Mg} / \mathrm{m}^{3}\right)$ was recorded under weedy check plot and minimum $\left(1.27 \mathrm{Mg} / \mathrm{m}^{3}\right)$ in $\mathrm{T}_{5}$ and $\mathrm{T}_{9}$ treatment and other chemical treatments $\mathrm{T}_{1}, \mathrm{~T}_{2}$, $\mathrm{T}_{3}, \mathrm{~T}_{4}, \mathrm{~T}_{6}, \mathrm{~T}_{7}, \mathrm{~T}_{8}$ have bulk density $1.31,1.30,1.28,1.29$, $1.30,1.32,1.32\left(\mathrm{Mg} / \mathrm{m}^{3}\right)$ respectively. Silt loam texture classes was observed in all the treatments plots. Based on the results, soil physical properties did not differ significantly under different treatments.

\subsection{Chemical properties of soils}

The data on the effect of various treatments on chemical properties ( $\mathrm{pH}, \mathrm{EC}$ and $\mathrm{OC}$ ) have been presented in Table-4. Chemical property ( $\mathrm{pH}, \mathrm{EC}$ and OC) of soil were not affected due to different weed management practices during the course of investigation, Slightly improvement in chemical properties of soil was recorded under weed free up to 60 DAS (3 HW) treatment. Among different weed management practices, minimum $\mathrm{pH}(8.00)$, EC (0.22 dSm-1) and maximum (organic carbon) $(3.35 \mathrm{~g} / \mathrm{kg})$ was recorded under weed free treatment up to 60 DAS (3 HW). Finally the result show the weed management practices did not found to affect the chemical properties of soil significantly after harvest the crop.

Table 4: Effect of weed management practices on Physico-chemical and biological properties of soil after harvest of wheat crop

\begin{tabular}{|c|c|c|c|c|c|c|c|}
\hline Symbols & Treatments & $\begin{array}{c}\mathbf{p H} \\
(1: 2.5)\end{array}$ & $\begin{array}{c}\text { EC } \\
(\mathrm{dSm} 1)\end{array}$ & $\left.\begin{array}{cc}O & C \\
(g / k g\end{array}\right)$ & $\begin{array}{c}\text { Bulk } \\
\text { density } \\
\left(\mathrm{mg} / \mathrm{m}^{3}\right) \\
\end{array}$ & $\begin{array}{c}\text { Bacteria } \\
\text { Population } \\
\left(\text { cfu } \times 10^{6}\right)\end{array}$ & \begin{tabular}{|c|} 
Fungus \\
Population \\
$\left(\right.$ cfu x10 $\left.{ }^{4}\right)$ \\
\end{tabular} \\
\hline $\mathrm{T}_{1}$ & Sulfosulfuran (POE) & 8.14 & 0.23 & 3.30 & 1.31 & 12 & 10 \\
\hline $\mathrm{T}_{2}$ & Clodinafop + metsulfuran (RM) (POE) & 8.16 & 0.23 & 3.5 & 1.30 & 18 & 12 \\
\hline $\mathrm{T}_{3}$ & Fenoxaprop p-ethyl +metribuzin (RM) (POE) & 8.18 & 0.23 & 3.30 & 1.28 & 18 & 12 \\
\hline $\mathrm{T}_{4}$ & Mesosulfuran methyl +iodosulfuran methyl (RM) (POE) & 8.22 & 0.22 & 3.32 & 1.29 & 18 & 11 \\
\hline $\mathrm{T}_{5}$ & Sulfosulfuran + metsulfuran (RM) (POE) & 8.23 & 0.23 & 3.35 & 1.27 & 22.70 & 13 \\
\hline $\mathrm{T}_{6}$ & Pendimethalin + 2,4-D (PE) & 8.21 & 0.23 & 3.30 & 1.30 & 15 & 11 \\
\hline $\mathrm{T}_{7}$ & Metribuzin (POE) & 8.21 & 0.24 & 3.35 & 1.32 & 12 & 10 \\
\hline $\mathrm{T}_{8}$ & 2,4-D Na (POE) & 8.18 & 0.23 & 3.35 & 1.32 & 12 & 10 \\
\hline $\mathrm{T}_{9}$ & Weed free up to 60 DAS (3 HW) & 8.00 & 0.22 & 3.35 & 1.27 & 32 & 15 \\
\hline
\end{tabular}




\begin{tabular}{|c|c|c|c|c|c|c|c|c|}
\hline $\mathrm{T}_{10}$ & Weedy check & 8.20 & 0.23 & 3.31 & 1.33 & 34 & 18 \\
\hline $\mathrm{SEm} \pm$ & & 0.07 & 0.01 & 0.02 & 0.01 & 0.30 & 0.33 \\
\hline C.D. at 5\% & & NS & NS & NS & NS & 0.90 & 0.97 \\
\hline
\end{tabular}

\subsection{Biological properties of soils}

Bacterial and fungal population after harvest of wheat crop have been presented in Table-4. Maximum bacterial population (43.00 $\mathrm{cfu} \times 10^{6} / \mathrm{g}$ soil) and fungal population (18.00 cfu $\times 10^{4} / \mathrm{g}$ soil) were recorded in weedy check treatment followed by weed free plot $(3 \mathrm{HW})$ bacterial population (32.00 cfu $\times 10^{6} / \mathrm{g}$ soil) and fungal population $\left(15.00 \mathrm{cfu} \times 10^{4} / \mathrm{g}\right.$ soil) respectively. The effect of herbicides application on soil microbial environment is always of great concern. The herbicides reaching in to the soil, are acted upon by several physical, chemical and biological forces and such action takes place almost immediately after they reach in to the soil while some inactivate of the herbicides may be caused by the chemical and physical forces. Soil micro-organisms ultimately account for the degradation of the herbicides. Most of the organic herbicides get degraded within a period of 3 to 6 months. Since soil factor such as moisture, temperature, $\mathrm{pH}$ and organic matter contents are known to greatly influence the microbial breakdown of the herbicides, have potential to control the weeds (Kumar et al. 2009) [4]. Weed control measures did not found to affect the physical and chemical properties of soil significantly after harvest the crop. However, the microbial population (bacteria, fungi) at 50 DAS were affected due to Application of herbicides. But, after harvest of the crop there was no any toxic effect on microbial properties due to degradation of herbicides. The herbicides are degraded by micro-organisms and the degraded products serve as carbon and energy sources due to which at harvest stage microbial population tended to improve. Among different weed control practices, weed free treatment recorded maximum microbial population. This might be mainly due to effect of aeration and sunlight into the soil by intercultural operations. The results are in agreement with Kumar et al. (2016), Kumar et al. $(2017)^{[19,18] .}$

\section{Conclusion}

There were no significant variations on the physico-chemical properties in the soil in the rhizosphere region of the transplanted kharif rice due to the application of herbicide bispyribac sodium $10 \% \mathrm{SC}$ at different doses. Though the microbial population in the soil in the rhizosphere region of the transplanted.

Based on the results, soil Physico-chemical properties of soils did not differ significantly under different herbicidal and nonherbicidal treatments. The maximum bacteria and fungus population observed in control plot due to no application of any weed management practices in control plot so more rhizosphere available for proliferation of bacteria and fungus than other treated plot. The decrease in the population of total bacteria and fungus in chemical herbicide applied plots up to different rates was due to competitive influence and the toxic effect as well as different residual effect of different chemical herbicides in soil. Microorganisms are able to degrade herbicides and utilize them as a source of biogenic elements for their own physiological processes. However, before degradation, herbicides have toxic effects on microorganisms, reducing their abundance, activity and consequently, the diversity of their communities. The toxic effects of herbicides are normally most severe immediately after application, when their concentrations in soil are the highest. Overall, there was no effect of weed management practices on Physico-chemical properties of soil but biological properties like bacteria and fungus population significantly affected by herbicides application in soils.

\section{Declaration of interest}

The authors report no conflicts of interest. The authors alone are responsible for the content and writing of this article.

\section{Acknowledgements}

Authors acknowledge financial and other support for this research work received through Department of soil science and agricultural chemistry, collage of agriculture, Narendra Deva University of agriculture and technology, Kumarganj, Ayodhya.

\section{References}

1. Angiras NN, Kumar S, Rana SS, Chandra N. Standardization of dose and time of application of herbicide to manage weeds in wheat. Himanchal Journal of Argil. Sci. 2008; 34(2):15-18.

2. Anonymous. Agricultural Statistics at a glance, Ministry of Agriculture and farmer welfare, Govt. of India, 2015.

3. Anonymous. United State Department of America, Govt. of America, 2017.

4. Chaudhry S, Rati JPS, Singh OP, Kumar D. Effect of tillage system and weed control methods on weeds, yields and economics of wheat (Triticum aestivum L.). Asian J. Bio Sci. 2009; 4 (2):254-257.

5. Chhipa KG, Pareek RG, Jain NK. Evaluation of sulfosulfuron alone in combination with other herbicides against weed in wheat. Haryana J Agron. 2005; 21(1):7273.

6. Cochran WG, Cox GM. Experimental design. First Indian Edition, 1959. Publishing House, Bombay. Calcutta. New Delhi and Madras. Das, T.K. and Yaduraju, N.T. (1999). Effect of weed competition on growth, nutrient uptake and yield of wheat as affected by irrigation and fertilizer. J Agric. Sci. 1970; 133(1):45-51.

7. Dharma Pal. Integrated weed management in late sown wheat. M.Sc. (Ag). Thesis submitted to department of Agronomy, NDUAT, Kumarganj, Ayodhya, 1999.

8. Das TK, Yaduraju NT. Effect of weed competition on growth, nutrient uptake and yield of wheat as affected by irrigation and fertilizer. J Agric. Sci. 1999; 133(1):45-51.

9. Dharma Pal. Integrated weed management in late sown wheat. M.Sc. (Ag). Thesis submitted to department of Agronomy, NDUAT, Kumarganj, Ayodhya, 1999.

10. Gill HS, Brar LS. Importance of herbicide in agriculture of Punjab and Haryana. Pesticides. 1975; 9(4):20-24.

11. Gill HS, Brar LS. Importance of herbicide in agriculture of Punjab and Haryana. Pesticides. 1975; 9(4):20-24.

12. Kumar R, Singh RS, Jaidev R, Singh. Effect of tillage system and weed control practices on soil health and yield of wheat under rice- wheat cropping system. Paper presented in BCISWS, DWR Jabalpur, 2014, 324p.

13. Kumar R, Verma BK, Ahamad A, Prakash V, Zaidi SFA, Kumar D. Biochemical properties of soil and yield of wheat as influence by tillage and weed Control measures. Annual plant and soil Res. 2015; 17(1):250-251.

14. Kumar R, Jaidev, Singh RS, Singh SS, Tripathi SK. Effect of soil enzymes and beneficial soil micro-organism 
as influence by weed management practices under ricewheat cropping system. New Agri. 2014; 25(1):79-81.

15. Kumar R, Jaidev, Singh RS, Singh SS, Tripathi SK. Effect of weed control measures on soil enzymes and beneficial soil micro-organism under rice-wheat cropping system. Paper published in BCISWC held at DWSR Jabalpur, 2014, 282p.

16. Kumar R, Jaidev, Singh SS, Singh AK, Singh RS, Singh BN. Effect of tillage system and weed control measures on soil micro flora. Paper presented in national symposium on heat threat to environment biodiversity and Agriculture productivity at TNAU Coimbatore, 2009, $121 \mathrm{p}$.

17. Kumar S, Malik RK. Differential response to sulfosulfuron under different irrigation frequencies to control weeds in wheat. Indian J Agron. 2001; 46(3):480484.

18. Kumar Raj, Singh RS, Jaidev, Singh G, Singh RP, Prakash $\mathrm{V}$ et al. Conservation system and weed control measure on yield and soil health in wheat. Biennial conference of the Indian society of weed science on "Doubling former' income by 2022: The role of weed science" MPUA \&T, Udaipur, India, 2017.

19. Kumar Raj, Singh RS, Jaydev, Verma B. Effect of tillage and herbicides on rhizospheric soil health in wheat. Indian journal of weed science. 2016; 48(2):1-5

20. Kumar Raj, Singh RS, Jaidev, Verma BK. Effect of tillage and herbicides on rhizospheric soil health in wheat. Indian journal of weed science. 2016; 48(2):220222.

21. Rangaswami G, Bragg Raj DG. Text book of agricultural microbiology (second edition), 2004, 200-204. 